\title{
Comparison of disinfectants by immersion and spray atomization techniques on the linear dimensional stability of different interocclusal recording materials: An in vitro study
}

\author{
Revathy Gounder ${ }^{1}$, B. V. J. Vikas ${ }^{2}$
}

Correspondence: Dr. Revathy Gounder

Email: revathygounder@yahoo.com

\begin{abstract}
'Department of Prosthetic Dentistry, Faculty of Saveetha Dental College and Hospital, Saveetha University, Chennai, Tamil Nadu, India, 2Department of Prosthodontics, Ex-Professor of Army College of Dental Sciences, Dr. NTR University of Health Sciences, Vijayawada, Andhra Pradesh, India
\end{abstract}

\section{ABSTRACT}

Objective: To evaluate and compare the effect of $0.5 \%$ chlorhexidine gluconate, $1 \%$ sodium hypochlorite, and $2 \%$ glutaraldehyde by immersion and spray atomization technique on the linear dimensional stability of Jet bite, Aluwax and Ramitec interocclusal recording materials. Materials and Methods: Three representative materials: Jet bite (addition silicone), Aluwax and Ramitec (polyether) were mixed according to manufacturer's instructions and then specimens were prepared according to the specifications of ISO 4823. All the specimens except the control (distilled water) were treated with disinfectant solutions $(0.5 \%$ chlorhexidine gluconate, $1 \%$ sodium hypochlorite, and $2 \%$ glutaraldehyde) for 30 and $60 \mathrm{~min}(n=10)$ by spray and immersion technique. Once removed from the solutions, the test samples were washed in water for $15 \mathrm{~s}$, dried and measured after $24 \mathrm{~h} 3$ times using a measuring microscope with an accuracy of $0.0001 \mathrm{~mm}$. Two-way ANOVA and Tukey's test with significance level of 5\% were used to assess the statistical data $(\alpha=0.05)$. Result: All groups showed no significant difference statistically, in linear dimension when disinfected for 30 min by spray or immersion technique. Polyether had significantly higher dimensional variation when immersed in sodium hypochlorite for $60 \mathrm{~min}$. Addition silicone showed the least dimensional change which ranged from $0.024 \%$ to $0.05 \%$, followed by polyether from $0.004 \%$ to $0.171 \%$ and Aluwax from $0.146 \%$ to $0.228 \%$. Conclusion: To preserve the dimensions and surface of the recording materials and effective microbial elimination, restrictions should be applied in the method of disinfection and time duration. However, using the disinfectants either by spray or immersion technique, the dimensional change was $<0.5 \%$ which was not clinically significant according to the American Dental Association specification no. 19 criteria within the first $24 \mathrm{~h}$.

Key words: Addition silicone, Aluwax, bite registration materials, dimensional stability, disinfection, interocclusal recording materials, polyether

\section{INTRODUCTION}

Interocclusal recording materials are used to transfer the interocclusal relationship from patient mouth to the lab. These are impression plaster, compound wax, resin, metal oxide paste, rubber base, and silicone materials. ${ }^{[1]}$ Any inaccuracy in the interocclusal record leads to occlusal errors in the final prosthesis. To minimize the necessity of occlusal adjustments, the chosen material should accurately capture the interocclusal relationship. Failure to capture an accuracy lead to a time-consuming chair-side adjustments, the need for remounting casts and possible refabrication of prosthesis. ${ }^{[2]}$

This is an open access article distributed under the terms of the Creative Commons Attribution-NonCommercial-ShareAlike 3.0 License, which allows others to remix, tweak, and build upon the work non-commercially, as long as the author is credited and the new creations are licensed under the identical terms.

For reprints contact: reprints@medknow.com

How to cite this article: Gounder R, Vikas B. Comparison of disinfectants by immersion and spray atomization techniques on the linear dimensional stability of different interocclusal recording materials: An in vitro study. Eur J Dent 2016;10:7-15.

DOI: $10.4103 / 1305-7456.175684$ 
Bite registration record acts as a significant source for cross-contamination; so the American Dental Association (ADA) issued guidelines for disinfecting impressions in 1988, 1991, and 1996. ${ }^{[3]}$ These must be disinfected immediately after their removal from the mouth. There are two important factors to consider when choosing a disinfectant namely, its ability to eliminate microbial contamination and its effect on the resultant material. The literature varies markedly in the concentration, type and immersion time of disinfection protocols, making it difficult to assess the appropriate method. ${ }^{[4]}$ There is also very little guidance provided by the manufacturers as to the most suitable disinfectants to use with their products.

Although numerous studies have been made on the accuracy and stability of impression, ${ }^{[5,6]}$ few studies on the dimensional stability of different interocclusal recording materials have been investigated ${ }^{[7-10]}$ but the effect of disinfection and its method on the dimensional accuracy of interocclusal recording materials have not been reported previously.

\section{MATERIALS AND METHODS}

Three commercially available dental interocclusal recording materials and three commonly available disinfectants were selected for this in vitro study [Tables $1 \mathrm{a}$ and $\mathrm{b}$ ]. A stainless steel die was prepared in accordance with the American National Standards Institute/ADA Council on Scientific Affairs specification no. 19 for linear dimensional changes that consisted of ruled block, mold, and riser [Figure 1]. The ruled block contained three horizontal lines $X, Y, Z(50 \pm 8,20 \pm 4,75 \pm 8 \mu \mathrm{m})$ perpendicular to two vertical lines $C D$ and $C^{\prime} D^{\prime}$ of $75 \pm 8 \mu \mathrm{m}$ each. The lines $\mathrm{CD}$ and $\mathrm{C}^{\prime} \mathrm{D}^{\prime}$ were separated from each other by $25 \mathrm{~mm}$. The distance between XZ lines was $5 \mathrm{~mm}$. The test mold was a cylinder with an inner and outer diameter of 30 and $38 \mathrm{~mm}$. The depth of the mold was $6 \mathrm{~mm}$ to place the record material. The riser was a stainless steel disk of diameter $29.9 \mathrm{~mm}$ and thickness of $3 \mathrm{~mm}$ [Figure 2] to retrieve specimen. Test block and ring mold were placed in an incubator (set at $35 \pm 1^{\circ} \mathrm{C}$ ) for conditioning for $15 \mathrm{~min}$ before manipulation of specimens.

\section{Manipulation of polyvinylsiloxane bite registration material}

The cartridge along with mixing tip was attached to an auto-mixing gun. The material was spread and pushed ahead of the syringe tip in a zigzag pattern with the tip buried in the material. A glass plate $(4 \times 4$ inches square) covered with polyethylene sheet was placed on the die over which a weight of $1 \mathrm{~kg}$ was kept and allowed to set for 4-5 min in a thermostatically controlled water bath to stimulate mouth condition [Figure 3].

Manipulation of Aluwax bite registration material For the Aluwax [Figure 4], the method was modified by submerging it in a $45^{\circ} \mathrm{C}$ water bath for 5 min using $5 \mathrm{ml}$ glass syringe. This was carried out by breaking the wax and putting it into the syringe before melting. After homogenous mixing, the material was injected into the mold.

\begin{tabular}{|c|c|c|c|}
\hline $\begin{array}{l}\text { Interocclusal } \\
\text { material type }\end{array}$ & Product & $\begin{array}{c}\text { Lot } \\
\text { number }\end{array}$ & Manufacturer \\
\hline $\begin{array}{l}\text { Polyvinylsiloxane } \\
\text { (addition type) }\end{array}$ & Jet bite & C44619 & $\begin{array}{l}\text { Coltene/Whaledent } \\
\text { AG, Switzerland }\end{array}$ \\
\hline Aluwax & $\begin{array}{l}\text { Aluwax bite and } \\
\text { Impression wax }\end{array}$ & 112811 & $\begin{array}{l}\text { Aluwax Dental } \\
\text { Products Co. } \\
\text { Michigan, USA }\end{array}$ \\
\hline Polyether & $\begin{array}{l}\text { 3M ESPE } \\
\text { Ramitec }\end{array}$ & $\begin{array}{l}521214(B) \\
519556(\mathrm{C})\end{array}$ & $\begin{array}{l}\text { 3M Dentschland } \\
\mathrm{GmbH} \text {, Germany }\end{array}$ \\
\hline
\end{tabular}

\begin{tabular}{lcccc}
\hline Table 1b: Various disinfecting agents tested \\
\hline Agents & $\begin{array}{c}\text { Concentration Product } \\
\text { (\%) }\end{array}$ & $\begin{array}{c}\text { Lot } \\
\text { number }\end{array}$ \\
\hline $\begin{array}{l}\text { Chlorhexidine } \\
\text { gluconate }\end{array}$ & 0.5 & V-consept & 13058 & $\begin{array}{l}\text { Vishal } \\
\text { Dentocare }\end{array}$ \\
$\begin{array}{l}\text { Sodium } \\
\text { hypochlorite }\end{array}$ & 1 & $\begin{array}{l}\text { Sodium } \\
\text { hypochlorite }\end{array}$ & $14012 \begin{array}{l}\text { Pvt. Ltd. India } \\
\text { Vishal } \\
\text { Dentocare } \\
\text { Pvt. Ltd. India } \\
\text { Johnson and } \\
\text { Johnson, India }\end{array}$ \\
\hline & 2 & Cidex & B3105 & \\
\hline
\end{tabular}

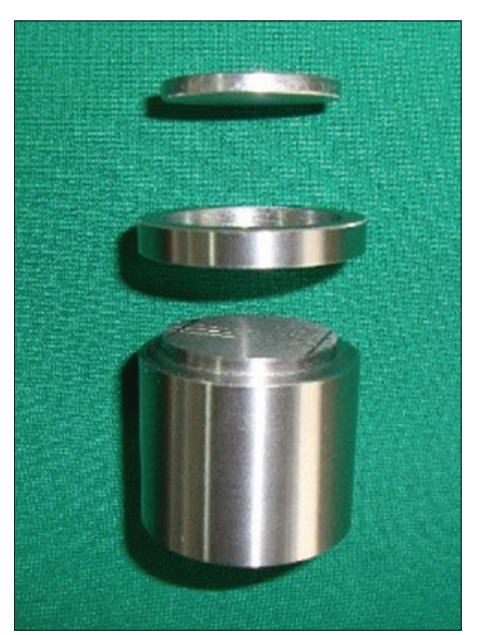

Figure 1: American National Standards Institute/American Dental Association No. 19 specified stainless steel die 


\section{Manipulation of polyether bite material}

The required amount of equal length of pastes were dispensed on the mixing pad and mixed for $45 \mathrm{~s}$ to get homogenous streak free mix. The mix was loaded

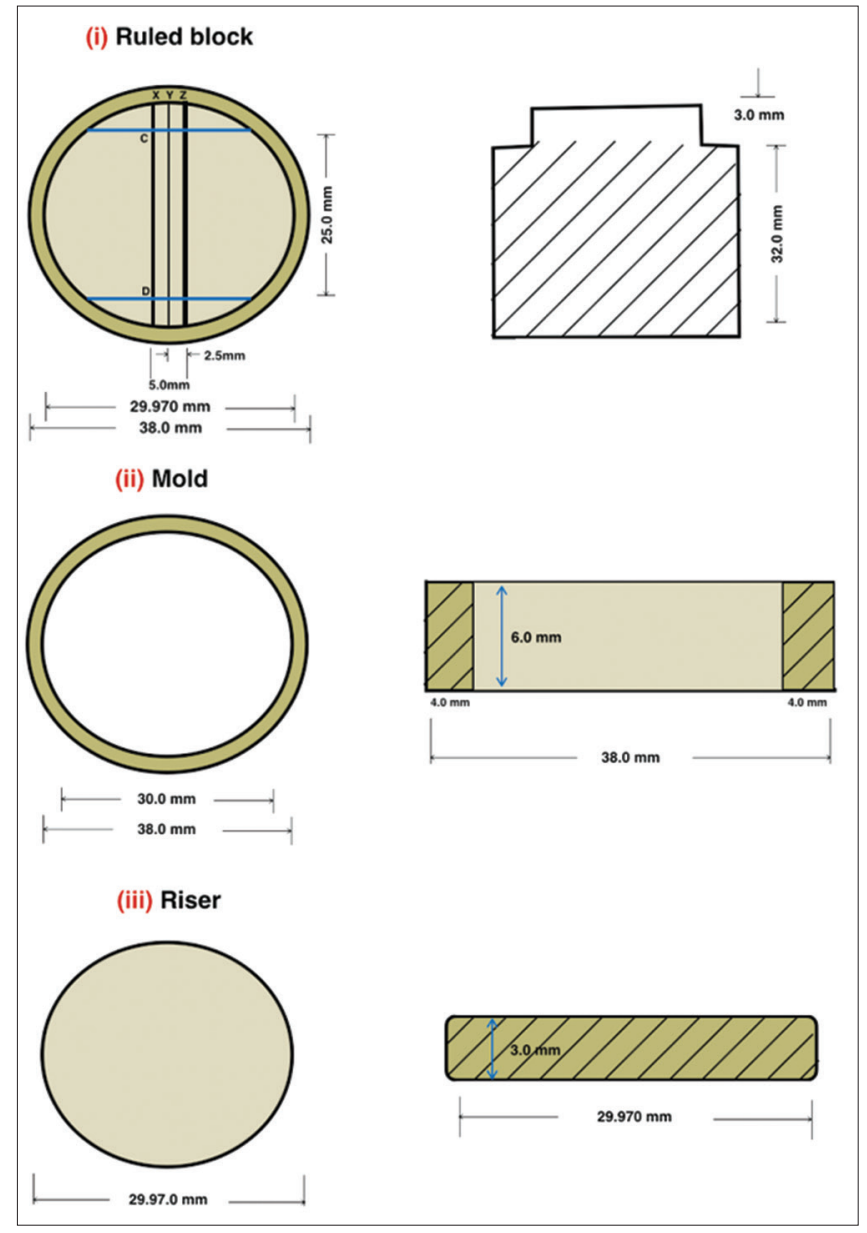

Figure 2: Systematic diagram of stainless steel (transverse and front view)

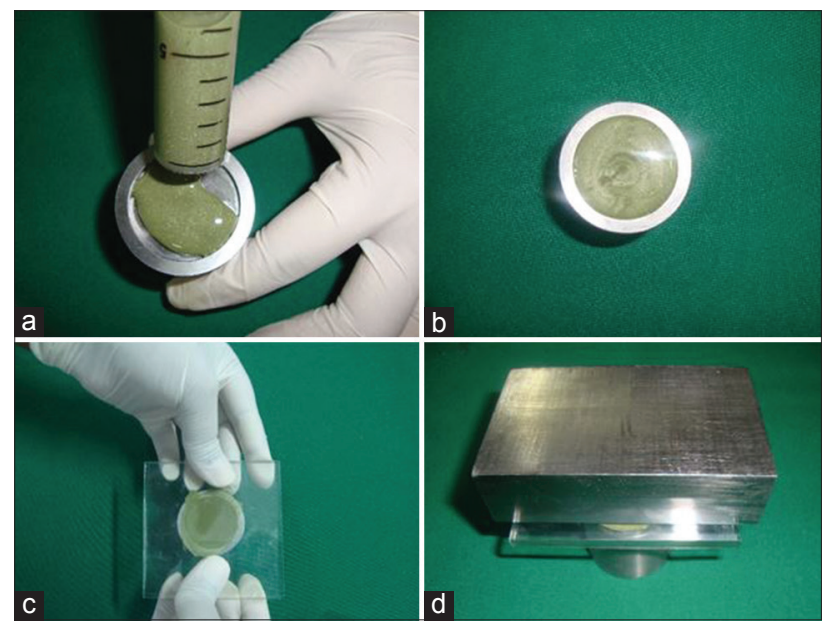

Figure 4: Manipulation of aluwax bite registration material. (a) Homogenously melted Aluwax in the glass syringe injected. (b) Material with in the mold. (c) Glass plate with sheet placed. (d) $1 \mathrm{~kg}$ weight kept over the die into a plastic syringe provided by the manufacturer. The mix was injected into the mold and spread same as other material [Figure 5].

\section{Preparation of samples}

Their testing were conducted in controlled laboratory conditions. These conditions were entailed the temperature $24 \pm 2{ }^{\circ} \mathrm{C}$ and relative humidity of $55 \pm 10 \%$. Specimens [Figure 6] were grouped as: Group A (Polyvinylsiloxane), Group B (Aluwax), and Group C (Polyether). These were subjected to the following disinfecting treatments based on ADA recommendations $0.5 \%$ chlorhexidine gluconate (Subgroup I), $1 \%$ sodium hypochlorite (Subgroup II), and 2\% glutaraldehyde (Subgroup III) solutions that
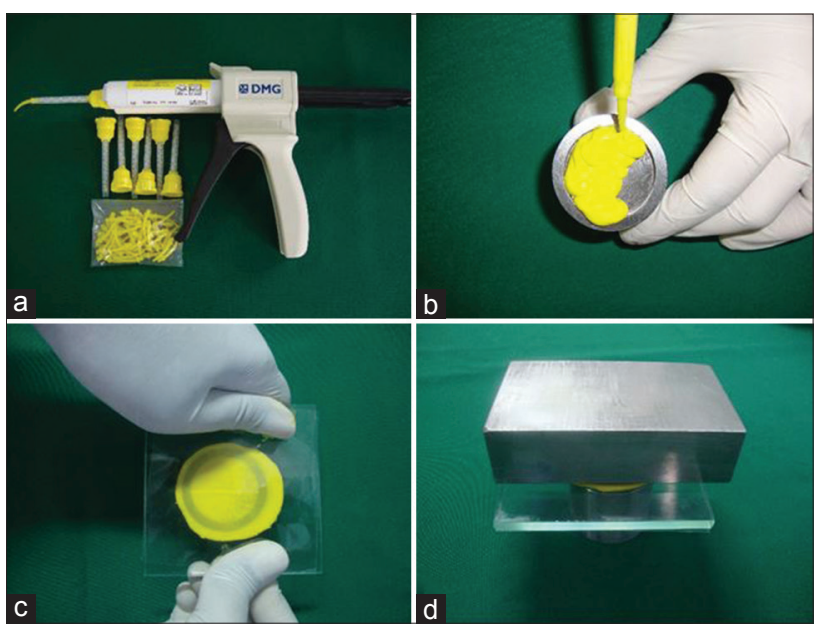

Figure 3: Manipulation of polyvinylsiloxane (a) jetbite (addition silicone) supplied in the form of catridge with automixing gun and tips. (b) Material injected to the mold. (c and d) Glass plate with sheet placed and $1 \mathrm{~kg}$ weight kept over die
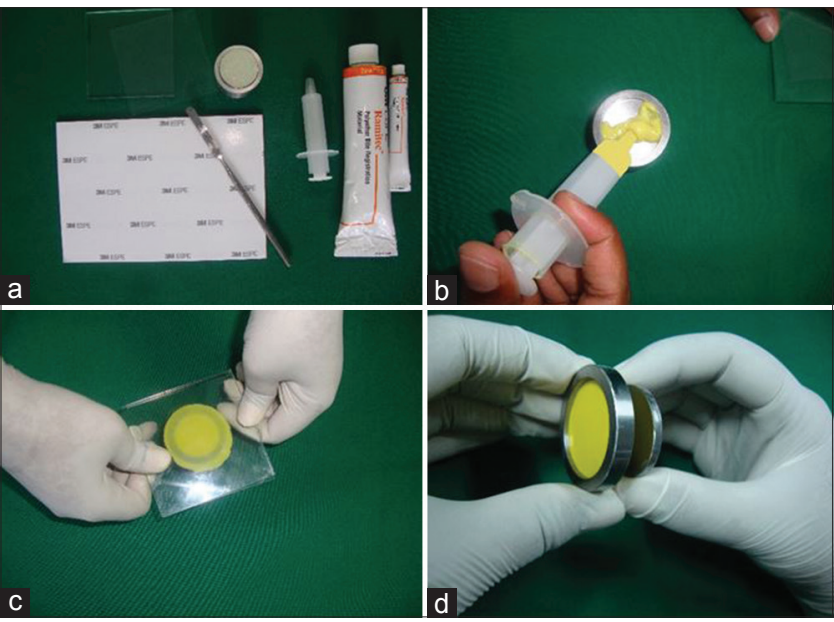

Figure 5: Manipulation of polyether bite material. (a) Apparatus for mixing ramitec (polyether) material. (b) Material spread over the surface of the die. (c) Head pressure applied till the metal ring was seen. (d) Specimen separated from the mold by using riser 
were used by two techniques; immersion and spray atomization. 60 Specimens from group A, $B$, and $C$ were immersed in $0.5 \%$ chlorhexidine (Subgroup I) solutions for $30 \mathrm{~min}(n=10$, total $=30)$ and $60 \mathrm{~min}(n=10$, total $=30)$ separately at room temperature [Figure $7 \mathrm{a}]$.

Sixty specimens from Group A, B, and Cwere immersed in $1 \%$ sodium hypochlorite (Subgroup II) solutions for $30 \mathrm{~min}(n=10$, total $=30)$ and $60 \mathrm{~min}(n=10$, total $=30)$ separately at room temperature.

Sixty specimens from Group A, B, and Cwere immersed in $2 \%$ glutaraldehyde (Subgroup III) solutions for $30 \mathrm{~min}(n=10$, total $=30)$ and $60 \mathrm{~min}(n=10$, total $=30)$ separately at room temperature.

Specimens $(n=10$, total $=180)$ were sprayed same as mentioned above (spray atomization technique) with all disinfectants until the complete surface of the specimens became wetted and sealed in a plastic bag for 30 and 60 min separately [Figure 7b]. ISO 9001:2000 certified spray bottle was used for spray atomization technique. It consisted of plain orifice nozzle with finger sprayer to propel contents from the container with no external source of compressed air being used. The same bottle was used for all the disinfectant solutions. After every usage, it was washed with distilled water and dried.

Specimens $(n=10$, total $=60)$ from each group were treated with distilled water (control) for 30 and $60 \mathrm{~min}$ separately. The sample size is listed in Table 2.

After disinfection, both control and test specimens were rinsed again under tap water for $10 \mathrm{~s}$. This was done to stimulate rinsing the impression after removal from the oral cavity and also after removal from the disinfectant solution.

Measurements of the specimens were taken after $24 \pm 1 \mathrm{~h}$. All the measurements were performed by the same operator. The distance between the cross lines $C D$ and $C^{\prime} D^{\prime}$ reproduced in the samples were measured at the intersection of these lines with the XYZ lines by Measuring Microscope (STM 6-LM, Olympus) [Figure 8] with $\times 10$ magnification $(0.0001 \mathrm{~mm}$ submicron precision).

The test block was measured five times to produce a mean value of $24.9150 \mathrm{~mm}$. According to ISO 4823, the following equation was used to calculate the mean percentage of change for each specimen.

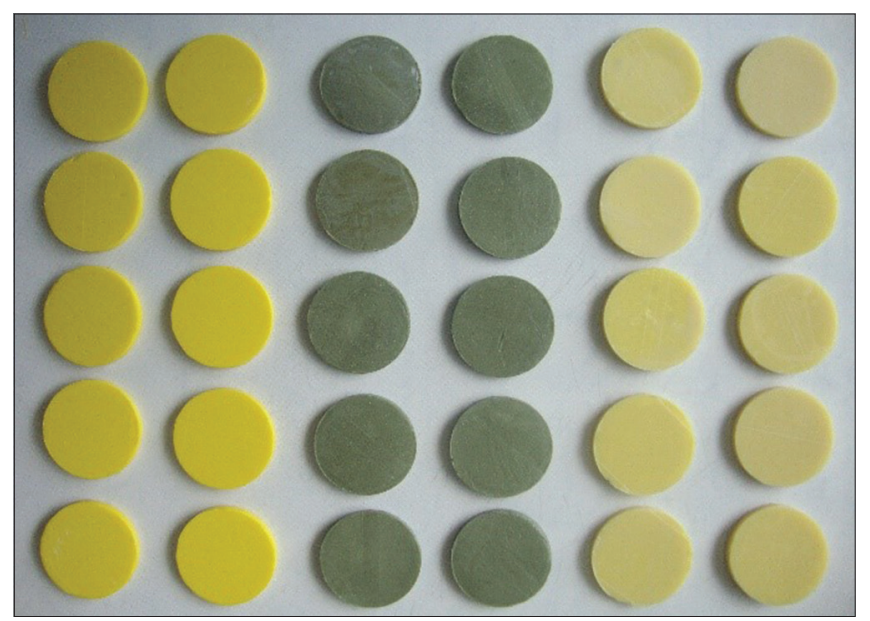

Figure 6: Test samples. Silicone (yellow), Aluwax (grayish green) and polyether (light yellow)
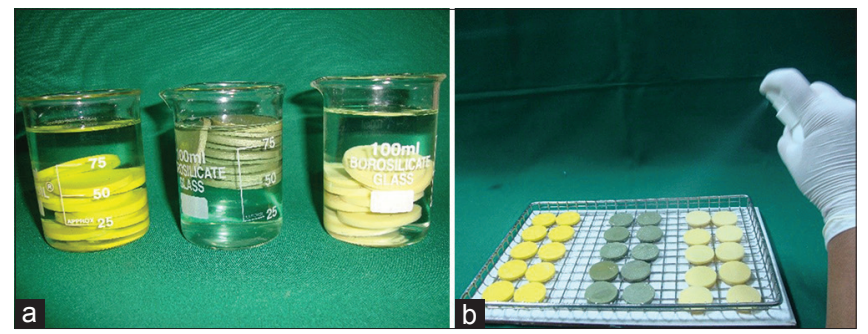

Figure 7: (a) Test samples immersed in disinfected solution. (b) Test samples were sprayed to wet all the surfaces

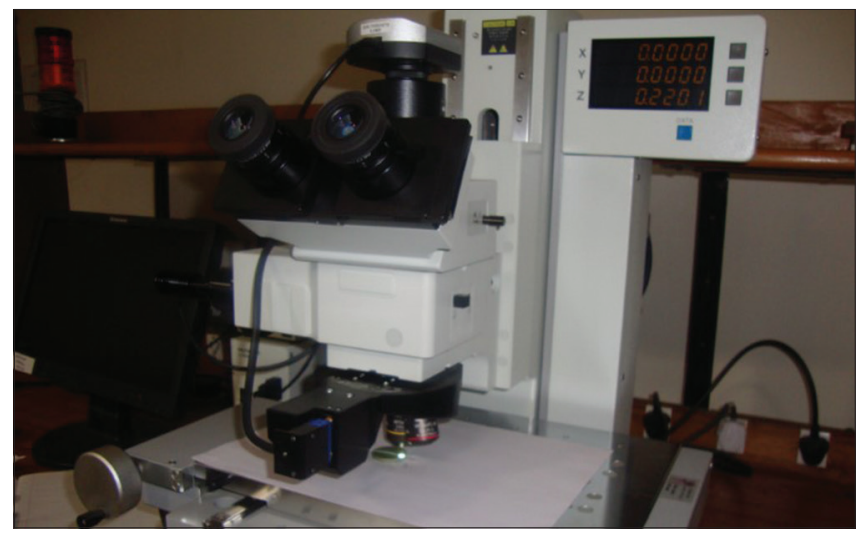

Figure 8: Specimen observed under measuring microscope

$\Delta \mathrm{L}=\frac{100\left(\mathrm{~L}_{1}-\mathrm{L}_{2}\right)}{\mathrm{L}_{2}}$

$\mathrm{L}_{1}=$ Mean distance measured between cross lines on the test block.

$\mathrm{L}_{2}=$ Distance measured between cross lines on the bite registration specimen.

The data obtained were analyzed with two-way ANOVA followed by post-hoc Tukey test $(\alpha=0.05)$. 


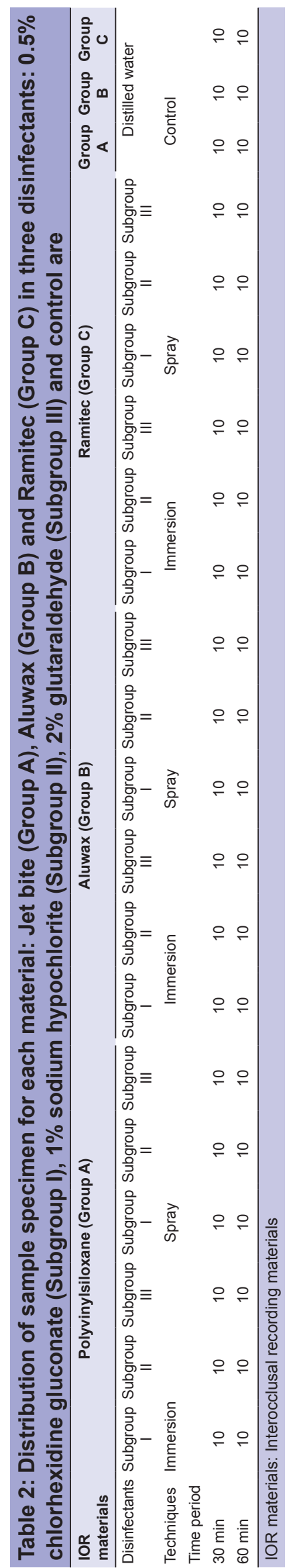

In addition, a qualitative analysis was done using Scanning electron microscope (Hitachi S-3700N SEM, Unified Engineering Inc., Aurora) to detect the topographic changes.

\section{RESULTS}

Comparison of 3 different groups by immersion technique for $30 \mathrm{~min}$ showed no statistically significant difference by ANOVA. There was a statistically significant difference in the mean values between the group and the subgroupsforeach group whenimmersed for $60 \mathrm{~min}$ [Table 3]. Post-hoc result showed that there was a significant interaction between subgroups of different groups. Within Group C (polyether), there was a statistically significant difference between subgroups and control [Table 4]. Subgroups for each material group showed no results when sprayed for 30 and $60 \mathrm{~min}$. Immersion and spray techniques were compared for 30 and 60 min by $t$-test, which showed no statistically significant difference except for the sodium hypochlorite in Group C for 60 min [Table 5].

Figure 9 showed statistically significant difference between 30 and $60 \mathrm{~min}(P=0.05)$ by immersion technique for each group, while spray technique did not showed any significant interaction when time period was increased except for Group B. Addition silicone showed [Figure 10] the least dimensional change which ranged from $0.024 \%$ to $0.050 \%$. Aluwax showed maximum dimensional change which ranged from $0.146 \%$ to $0.228 \%$. $P=0.0031$ for polyether when immersion period was increased for $60 \mathrm{~min}$. Dimensional change of polyether ranged from $0.04 \%$ to $0.71 \%$. Scanning electron microscopic analysis was made to determine the surface topography. Three samples from each subgroup for different time intervals were selected. Specimens were gold coated for $90 \mathrm{~s}$ with a plasma current of $18-20 \mathrm{~mA}$. At low

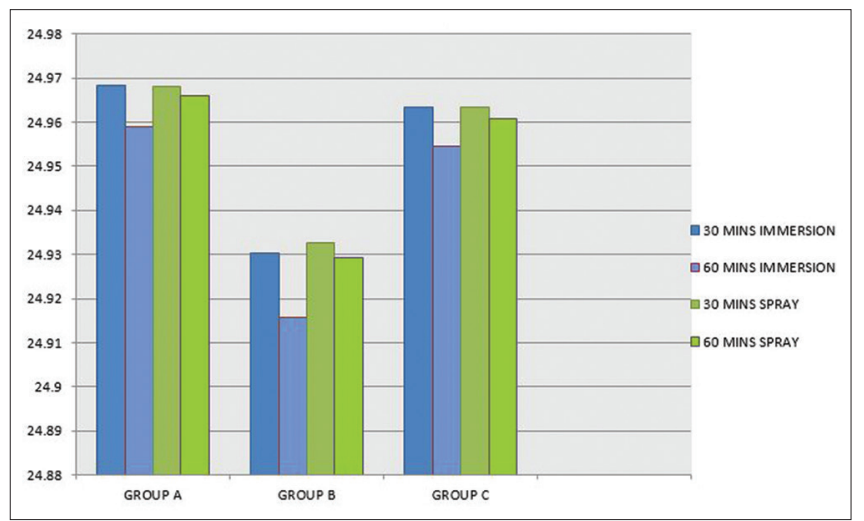

Figure 9: Comparison of 30 and $60 \mathrm{~min}$ of immersion and spray techniques in three material groups 


\begin{tabular}{|c|c|c|c|c|c|}
\hline Source of variation & Degrees of freedom & Sum of squares & Mean sum of squares & $F$ & $P$ \\
\hline \multicolumn{6}{|l|}{ Main effects } \\
\hline Between groups & 2 & 0.0553 & 0.0277 & 220.2066 & $0.00001^{*}$ \\
\hline Within groups & 3 & 0.0046 & 0.0015 & 12.1830 & $0.00001^{*}$ \\
\hline \multicolumn{6}{|l|}{ 2-way interaction effects } \\
\hline Between $\times$ within groups & 6 & 0.0029 & 0.0005 & 3.8163 & $0.0017^{*}$ \\
\hline Error & 108 & 0.0136 & 0.0001 & & \\
\hline Total & 119 & 0.0763 & & & \\
\hline
\end{tabular}

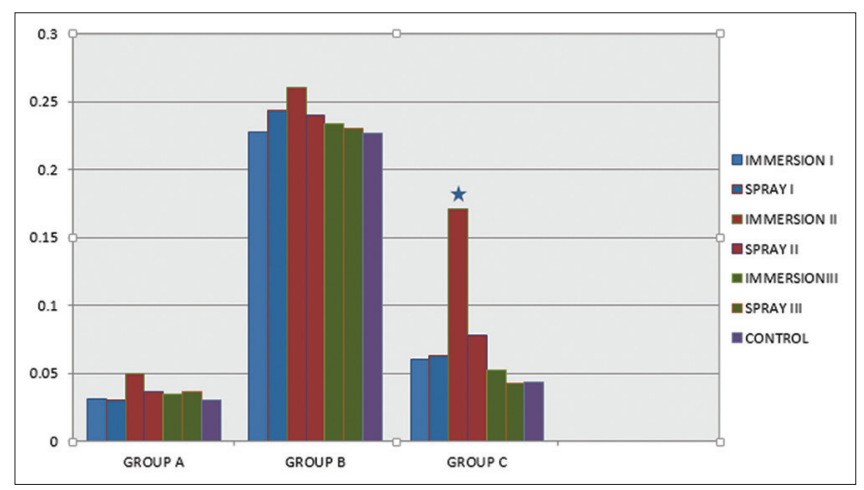

Figure 10: Comparison of immersion and spray techniques with dimensional changes of three materials in disinfectants at $60 \mathrm{~min}$. Asterisk indicates significant difference, $P<0.05$

magnification, all disinfected and nondisinfected samples were able to produce the full length of $20 \mu \mathrm{m}$ wide line. At $\times 600$, trough and ridge was appreciable for polyether and silicone with clean demarcation while Aluwax showed poor demarcation [Figure 11a-c]. Further magnification at $\times 2.5$ [Figure 12], $60 \mathrm{~min}$ immersed polyether samples showed the micro-pits and voids which clearly demarcates the interferences in the polymerization reaction.

\section{DISCUSSION}

According to this study, all the interocclusal record materials showed variations when disinfected by immersion so null hypothesis were rejected. Based on spray technique for 30 and $60 \mathrm{~min}$, subgroups for each material group showed no results, which is consistent with results of studies by Oderinu et al., ${ }^{[11]}$ Juggar et al. ${ }^{[12]}$ and Habu et al. ${ }^{[13]}$ Chlorhexidine is a cationic bis-guanide which consists of two symmetric 4-chlorophenyl rings and two biguanide groups connected by central hexamethylene chain. Its efficacy is due to the interaction of positive charge of the molecule and negatively charged phosphate groups on the microbial cell walls. Glutaraldehyde solution acts by fixating cell membranes, blocking the release of cellular components

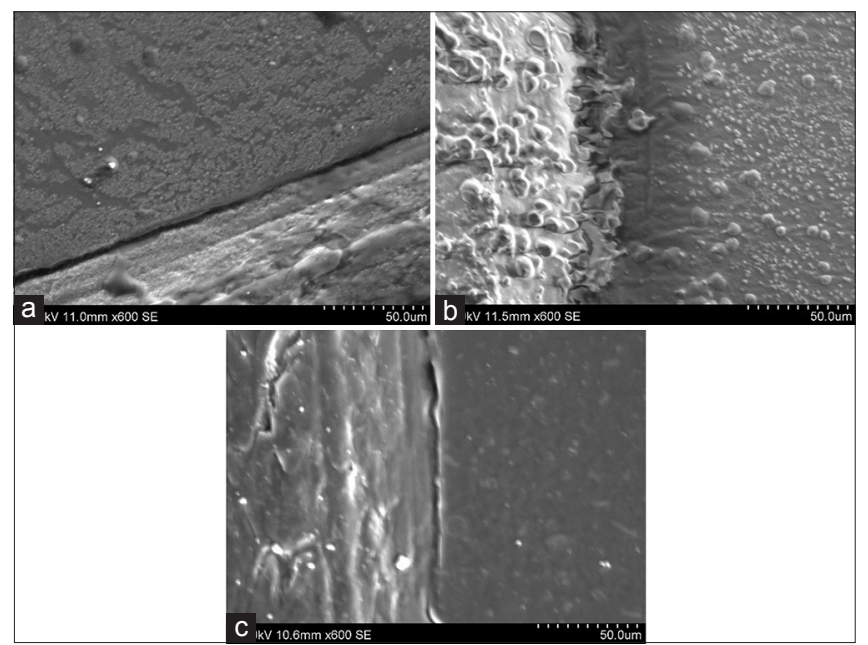

Figure 11: (a) Disinfected specimen of addition silicone at $\times 600$. (b) Disinfected specimen of Aluwax at $\times 600$. (c) Disinfected specimens of polyether at $\times 600$

and consequently killing the micro-organisms. The performance of sodium hypochlorite is based on cell oxidation. ${ }^{[14]}$ A study by Silva and Salvador ${ }^{[15]}$ Frederick et al..$^{[16]}$ and Drennon et al. ${ }^{[17]}$ showed that disinfection of impression by spray appeared to be as efficacious as immersion and unlike the immersion method, it does not cause any dimensional changes. In this study, polyether showed varied dimension with sodium hypochlorite when immersed for $60 \mathrm{~min}$. Since sodium hypochlorite is both an oxidizing and hydrolyzing agent. They are strongly alkaline, hypertonic, and typically have normal concentrations of $10-14 \%$ available chlorine. They deteriorate with time, exposure to light, temperature, and contamination with metallic ions. Chlorine compound is highly reactive and could react and fix on the material. ${ }^{[4,18,19]}$ The dimensional change might be due to reaction of chlorine compound with sulfonic ether which interferes with the polymerization reaction and produces distortion. ${ }^{[16]}$ Addition silicone showed the least dimensional variations among all, but showed significant difference in dimensional change with time when disinfected for longer period $(60 \mathrm{~min})$ 


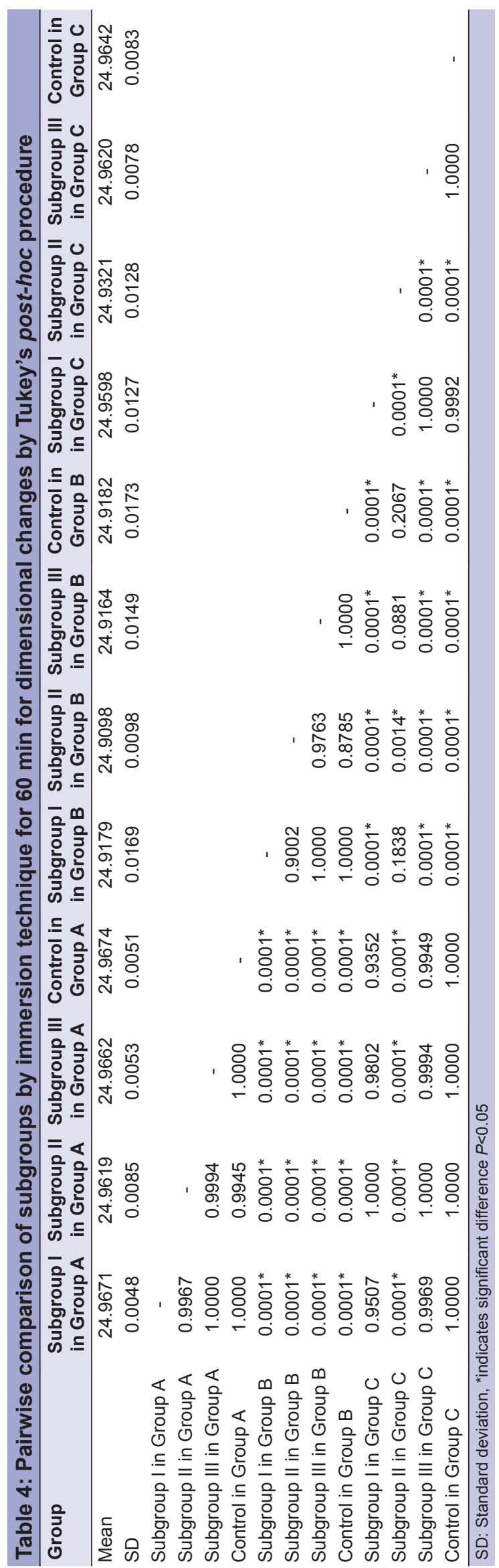

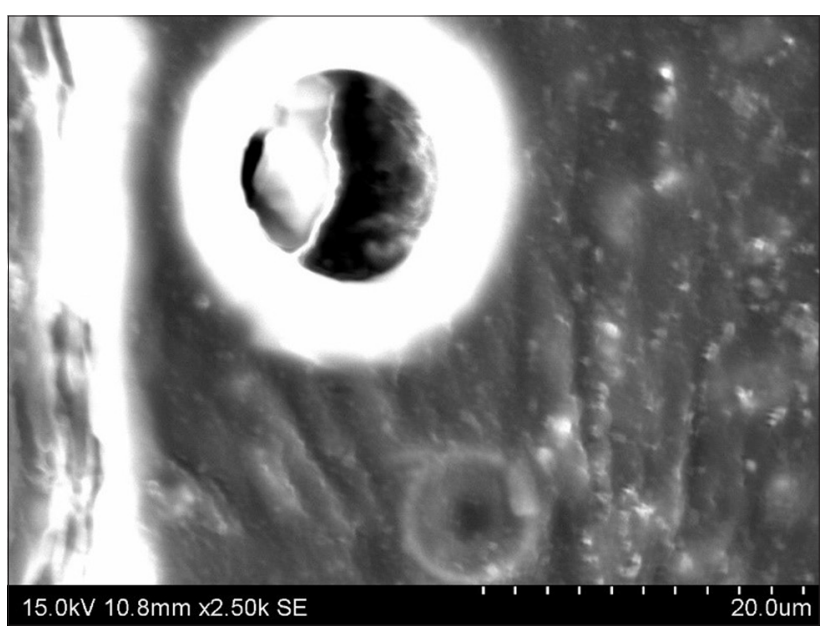

Figure 12: Polyether specimen treated with $1 \%$ sodium hypochlorite solution by immersion technique at $2.50 \mathrm{kx}$

in disinfectant solutions. It might be due to the addition of surfactants to improve its ability to reproduce details. The presence of these agents improves the compatibility with water and increases the sorption of water when impressions are immersed for longer period. ${ }^{[20]}$

Aluwax has gained wide acceptance for interocclusal record transfer, however studies showed that waxes contain aluminum or copper particles which have flow rate of $2.5-22 \%$ at $37.5^{\circ} \mathrm{C}$ so that they are susceptible to distortion upon removal from the mouth. ${ }^{[21]}$ Variation in the dimension was might be attributed to the greater coefficient of thermal expansion and distortion due to stress release. ${ }^{[22-24]}$

The total percentage dimensional changes that occurred during the disinfection process ranged from $0.03 \%$ to $0.30 \%$. To put the current result in context, the ADA specifies that impression materials should not exhibit more than $0.5 \%$ dimensional change in the first $24 \mathrm{~h}$ and all the materials investigated in this study satisfied the criteria. ${ }^{[25]}$ Future research should make an attempt to measure the linear measurements directly on the impressions to see if there are any errors that could be introduced during articulation of the casts.

\section{CONCLUSION}

Within the limitation of the study, the dimensional change of addition silicone, Aluwax and polyether after disinfection in $0.5 \%$ chlorhexidine gluconate, $1 \%$ sodium hypochlorite and $2 \%$ glutaraldehyde for 30 or $60 \mathrm{~min}$ is clinically acceptable. The tested specimens gave the results which are within the limits of ADA Specification no. 19. For 60 min immersion disinfection time period, sodium hypochlorite had 


\begin{tabular}{|c|c|c|c|c|c|c|}
\hline \multirow[t]{2}{*}{ Group } & \multicolumn{2}{|c|}{ Immersion technique } & \multicolumn{2}{|c|}{ Spray technique } & \multirow[t]{2}{*}{$t$} & \multirow[t]{2}{*}{$P$} \\
\hline & Mean & SD & Mean & SD & & \\
\hline Subgroup I in Group A & 24.9671 & 0.0048 & 24.9651 & 0.0078 & 0.6947 & 0.4961 \\
\hline Subgroup II in Group A & 24.9619 & 0.0085 & 24.9660 & 0.0053 & -1.3015 & 0.2095 \\
\hline Subgroup III in Group A & 24.9662 & 0.0053 & 24.9660 & 0.0061 & 0.0938 & 0.9263 \\
\hline Control in Group A & 24.9674 & 0.0051 & 24.9674 & 0.0051 & 0.0000 & 1.0000 \\
\hline Subgroup I in Group B & 24.9179 & 0.0169 & 24.9140 & 0.0229 & 0.4340 & 0.6694 \\
\hline Subgroup II in Group B & 24.9098 & 0.0098 & 24.9149 & 0.0227 & -0.6463 & 0.5263 \\
\hline Subgroup III in Group B & 24.9164 & 0.0149 & 24.9183 & 0.0112 & -0.3336 & 0.7426 \\
\hline Control in Group B & 24.9032 & 0.0317 & 24.9032 & 0.0317 & 0.0000 & 1.0000 \\
\hline Subgroup I in Group C & 24.9598 & 0.0127 & 24.9593 & 0.0122 & 0.0844 & 0.9336 \\
\hline Subgroup II in Group C & 24.9321 & 0.0128 & 24.9556 & 0.0120 & -4.2342 & $0.0005^{\star}$ \\
\hline Subgroup III in Group C & 24.9620 & 0.0078 & 24.9644 & 0.0067 & -0.7539 & 0.4606 \\
\hline Control in Group C & 24.9614 & 0.0100 & 24.9614 & 0.0100 & 0.0000 & 1.0000 \\
\hline
\end{tabular}

significantly affected polyether $(P=0.0005)$. Therefore, spray atomization technique can be recommended for polyether disinfected with sodium hypochlorite, to preserve dimensional stability, whereas both spray or immersion technique can be safely used with the other two disinfectants for addition silicone and Aluwax. In addition, dimensional stability of interocclusal recording materials was found to decrease with the increase in immersion time period.

\section{Clinical implications}

For polyether interocclusal record, restrictions based on type, duration, and method of disinfection must be applied to preserve the accuracy of the impression and effective microbial elimination.

\section{Financial support and sponsorship}

Nil.

\section{Conflicts of interest}

There are no conflicts of interest.

\section{REFERENCES}

1. Anusavice KJ. Impression materials. Phillips' Science of Dental Materials. 11 ${ }^{\text {th }}$ ed. St. Louis: Saunders; 2011. p. 253.

2. Pipko DJ, Khassa S. An in vitro study of the effect of different occlusal registration materials on the reproducibility of mounting casts. J Indian Prosthodont Soc 2009;9:24-7.

3. Marcinak CF, Young FA, Draughn RA, Flemming WR. Linear dimensional changes in elastic impression materials. J Dent Res 1980;59:1152-5.

4. Taylor RL, Wright PS, Maryan C. Disinfection procedures: Their effect on the dimensional accuracy and surface quality of irreversible hydrocolloid impression materials and gypsum casts. Dent Mater 2002;18:103-10.

5. Guler U, Budak Y, Ruh E, Ocal Y, Canay S, Akyon Y. Effect of mixing techniques on bacterial attachment and disinfection time of polyether impression material. Eur J Dent 2013;7 Suppl 1:S54-9.

6. Kamble SS, Khandeparker RV, Somasundaram P, Raghav S, Babaji RP,
Varghese TJ. Comparative evaluation of dimensional accuracy of elastomeric impression materials when treated with autoclave, microwave, and chemical disinfection. J Int Oral Health 2015;7:22-4.

7. Sweeney S, Smith DK, Messersmith M. Comparison of 5 types of interocclusal recording materials on the accuracy of articulation of digital models. Am J Orthod Dentofacial Orthop 2015;148:245-52.

8. Tejo SK, Kumar AG, Kattimani VS, Desai PD, Nalla S, Chaitanya KK. A comparative evaluation of dimensional stability of three types of interocclusal recording materials-an in vitro multi-centre study. Head Face Med 2012;8:27.

9. Anup G, Ahila SC, Vasanthakumar M. Evaluation of dimensional stability, accuracy and surface hardness of interocclusal recording materials at various time intervals: An in vitro study. J Indian Prosthodont Soc 2011;11:26-31.

10. Iwaki Y, Wakabayashi N, Igarashi Y. Dimensional accuracy of optical bite registration in single and multiple unit restorations. Oper Dent 2013;38:309-15.

11. Oderinu OH, Adegbulugbe IC, Shaba OP. Comparison of the dimensional stability of alginate impressions disinfected with $1 \%$ sodium hypochlorite using the spray or immersion method. Nig Q J Hosp Med 2007;17:69-73.

12. Jagger DC, Al Jabra O, Harrison A, Vowles RW, McNally L. The effect of a range of disinfectants on the dimensional accuracy of some impression materials. Eur J Prosthodont Restor Dent 20s04;12:154-60.

13. Habu H, Uchida H, Nagai M, Hiraguchi H. Study on the disinfection of alginate impressions 2 . Dimensional stability and surface roughness after immersing or spraying treatment with povidone-iodine solution. Shika Zairyo Kikai 1989;8:701-5.

14. McDonnell G, Russell AD. Antiseptics and Disinfectants; activity, action and resistance. Clin Microbiol Rev 2001;14:227.

15. Silva SM, Salvador MC. Effect of the disinfection technique on the linear dimensional stability of dental impression materials. J App Oral Sci 2004;12:244-9.

16. Rueggeberg FA, Beall FE, Kelly MT, Schuster GS. Sodium hypochlorite disinfection of irreversible hydrocolloid impression material. J Prosthet Dent 1992;67:628-31.

17. Drennon DG, Johnson GH, Powell GL. The accuracy and efficacy of disinfection by spray atomization on elastomeric impressions. J Prosthet Dent 1989;62:468-75.

18. Tullner JB, Commette JA, Moon PC. Linear dimensional changes in dental impressions after immersion in disinfectant solutions. J Prosthet Dent 1988;60:725-8.

19. Matyas J, Dao N, Caputo AA, Lucatorto FM. Effects of disinfectants on dimensional accuracy of impression materials. J Prosthet Dent 1990;64:25-31.

20. Rubel BS. Impression materials: A comparative review of impression materials most commonly used in restorative dentistry. Dent Clin North Am 2007;51:629-42.

21. Skurnik H. Resin registration for interocclusal records. J Prosthet Dent $1977 ; 37: 164-72$ 
Gounder and Vikas: To study the linear dimensional stability of different interocclusal recording materials after disinfection

22. Millstein PL, Kronman JH, Clark RE. Determination of the accuracy of wax interocclusal registrations. J Prosthet Dent 1971;25:189-96.

23. Millstein PL, Clark RE. Determination of the accuracy of laminated wax interocclusal wafers. J Prosthet Dent 1983;50:327-31.

24. Craig RG. Restorative Dental Materials. $10^{\text {th }}$ ed. St. Louis: Mosby; 1997. p. 302-3.

25. ANSI/ADA American National Standards Institute/American Dental Association Specification No. 19 for non-aqueous, elastomeric dental impressions. J Am Dent Assoc 1977;94:733-74.

\begin{tabular}{|l|l|}
\hline \multicolumn{2}{|c|}{ Access this article online } \\
\hline Quick Response Code: \\
\hline
\end{tabular}

